\title{
DIVORCE FOR THE UNWORTHY: SPECIFIC GROUNDS FOR DIVORCE
}

\author{
PaUL SAYRE* \\ "... and the spurns that patient merit of the unworthy takes. ..." \\ Hamlet, Act III, Scene I. \\ The Anomalous Situation
}

Hamlet wasn't the only one who thought the unworthy often secured advantages which they certainly did not deserve, and whatever else Hamlet knew about the "unworthy" in general, he didn't think about the unworthy in divorce litigation." The only absolute divorce they had then was by act of Parliament, and this was so expensive and so rare that the merits of the litigants were not of much public concern. But the unworthy among divorce litigants now may well be more numerous than the worthy ones, and they do constitute a significant part of the total population. If, in such a frequent thing as divorce, so far as litigation goes, injustice is done in that the worthy fail and the unworthy succeed, then surely it is time for the legal profession itself to look into this matter and to try to bring about results that do not bring discredit upon the law.

If we are to prevent the shocking if not indeed farcical result of having injustice prevail generally in divorce litigation, we must consider whether our bases for divorce are calculated to reach just results in view of the very special character of marriage and divorce against other claims litigated in our courts.

In general, our system of law is an adversary one; we seek to reach truth through contest, the contesting parties each representing his own interest, with a real contest in which the other contestant is striving his best to succeed also.

-A.B. I916, Harvard University; J.D. I920, University of Chicago; S.J.D. 1925, Harvard University. Professor of Law, State University of Iowa. President, National Council on Family Relations, r937I939.

${ }^{1}$ Of course, from the outset, we have in our minds the shocking fact that the United States has by far the highest divorce rate among the so-called civilized nations of the world. Of these excessive divorces, by rather common consent, a large number are purely frothy or trivial, so far as actual causes go. It is not the purpose of this paper to pass on the wisdom or unwisdom of particular grounds for divorce or of allowing divorce only for such limited grounds as adultery or desertion. But it is our purpose to consider ways of eliminating these purely needless divorces. In fact, our intent is to do so by a new method of considering all divorces, rather than a change in the specific grounds for divorce.

True, this we might call an indirect way of reducing divorces, but in divorce law many things are done indirectly. For instance, in the U.S.S.R., the grounds for divorce are still very trivial as they have been from the beginning of the Communist regime. But the actual number of divorces has been greatly reduced, and by a method which seems fantastic for a country that substantially denies private property. It is done by the burden of court procedure, and especially the cost in total fees for securing a divorce. 
But this elementary basis of our litigation generally simply does not prevail in divorce litigation. It is perhaps the one exception in our whole law to the general rule that there is a real contest for the courts to decide. Indeed, we hold specifically that if it is a "moot" case, the courts will refuse to hear it. But the surveys of divorce litigation show that much less than one tenth of the actual divorce cases in the courts involve a real contest on the question of granting the divorce at all. A slightly larger percentage show an apparent contest on the merits. But in fact the contest is not over granting the divorce but solely over the amount of the alimony, or the custody of the children, while the defendant is perhaps as anxious as the plaintiff to have the divorce itself granted. ${ }^{2}$

In a word, divorce litigation is the one striking exception in the whole field of our law to the method that the defendant is trying to prevent the plaintiff from succeeding and that this real contest will bring out the true facts and the best legal construction of those facts.

Of course, if the parties have agreed in advance not to contest the divorce, there is a technical case of collusion, which would prevent granting of the decree, and would make the parties themselves subject to contempt proceedings. But this is not true in a practical sense. Especially when the grounds for divorce include no serious offenses, most marriages involve difficult incidents that can truthfully be presented as grounds for divorce. Where we have specific grounds for divorce, therefore, the real issue is whether or not the parties choose to seek a divorce on the technical grounds for divorce which they undoubtedly have. Agreement on this question and on the whole matter of alimony and custody does not involve collusion or any technical fraud on the court.

Under our statutes, however, we find that the legal grounds for divorce are specific acts of wrongdoing, and it is by proving the doing of these acts that a divorce decree is secured. And most of the grounds for divorce involve moral turpitude in theory: adultery, desertion, cruelty. ${ }^{3}$ In fact, of course, the desertion may be fictitious, as well as the act of adultery. And the cruelty may be utterly trivial or fictitious as the parties themselves elect. We must remember again that a specific cause of action presupposes proof of that wrongdoing. But in divorce litigation this is exactly what we do not have. Actually, both parties want the divorce. Usually it is a default case with no contest at all. Almost never is there

${ }^{2}$ For divorce statistics, see Marsfall and May, The Divorce Court (Vol. I, 1932; Vol. II, r933).

${ }^{3}$ A number of jurisdictions even have statutes which provide for "indignities" to the complaining spouse as grounds for divorce. Under such statutes, the right to a divorce for "indignities" is separate and apart from the relief for cruelty. For a comprehensive discussion of this type of statute see Note, Indignities as Grounds for Divorce, I WYo. L. J. 187 (1947).

For additional articles and comments on divers grounds for divorce presented to the courts, see Comment, Court-Martial Conviction as a Ground for Divorce, 28 B. U. L. REv. 222 (1948); Alexander, Our Legal Horror, I9 J. B. A. KAN. $32 \mathrm{I}$ (I95I); Comment, Habitual Cruelty, r9 Aust. L. J. $27 \mathrm{I}$ (1945); Comment, Persons-Divorce-Insanity as Grounds-Requirement of Pleading and Proving Ability to Stupport, 24 So. Calif, L. Rev. 207 (I95I); Comment, Willful Refusal to Have or Bear Children as Grounds for Divorce or Annulment, 55 YALE L. J. 596 (I946); Comment, Divorce, Wife's Cruel and Inhuman Treatment, 18 TENs. L. Rev. 719 (1945). 
a real contest on the divorce itself. ${ }^{4}$ Would it not seem that this situation, so strikingly different from other fields of the law in which real contests occur, should have a method adapted to its needs, and not a method that is entirely fictitious and false? This scheming by the parties themselves in an atmosphere of falsehood, as well as the fraud on our courts, works a degrading influence on the quality of our civilization and brings our whole system of justice into disrepute.

If we consider one particular phase of divorce law, perhaps this general folly of relying solely on specific grounds for divorce will be more clear. The whole technique of affirmative defenses is one of the weakest parts of divorce law itself. Many writers and practicing lawyers think that at least the defense of recrimination should be entirely abolished. ${ }^{5}$ In straight logic it is difficult to defend, since normally in the law one is liable for his own wrongdoing, at least in the field of torts, even though the defendant has been guilty of some separate and collateral wrongdoing. ${ }^{B}$ The case of an assault by way of self-defense is really not an exception since the theory there is that the attack has been excused from the beginning, because of the first attack by the defendant. In recrimination, however, the offense by the plaintiff

- Of course, divorce involves the determination of a status, and the state itself is always an implied

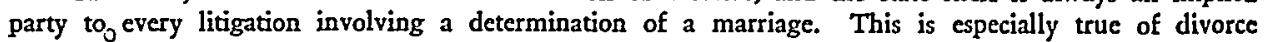
litigation. Thus in a non-contest divorce hearing, the grounds for divorec must nevertheless be proved, even though the defendant does not contest them. The judge himself will require the presentation of evidence giving satisfactory proof of the truth of the alleged grounds for the divorce.

It might seem that this would protect the public against trivial divorces, since the real ground for the divorce would have to be proved. The difficulty here, as in so many other cases in this field, is due to the actual practice in our courts. For instance, it has been reliably estimated that in non-contest divorce cases (including perhaps most of these that go by default) the divorce is granted within five minutes after the complainant begins to give or introduce his evidence in support of his petition.

Thus proof of the grounds for divorce is required, but when there is no contest, this proof is usually perfunctory and any real finding by the court of wrongdoing simply does not exist. Once more, we have the adversary method. We seek to find truth through contest. When there is no contest, the whole method breaks down.

${ }^{5}$ Under the doctrine of recrimination, where both are substantially at fault, and the divorce is contested on this ground, there can be no divorce. See Arnaboldi v. Arnaboldi, 10r N. J. Eq. 126, 138 Atl. 116 (1927). For a critical discussion of the doctrine itself see Note, Recrimination as a Defense in Divorce Actions, 28 IOWA I. REv. 34 I (I943).

The proposed doctrine of giving divorce only after at least one party has made an effort would in itself abolish the doctrine of recrimination. But it would not be a relaxation in a sense of making divorce casy for wrongdoers. Thus if both parties continued to be at fault, as in a situation where recrimination applies now, there would also be no divorce under this new doctrine. This new test does seem to free the law of divorce from the needless fatalism of recrimination and at the same time it requires honorable effort in sustaining a marriage and permits divorce only for rcal rather than artificial cause even where the marriage has failed. Also, of course, the defendant who has not made adequate effort under the new rule, would be penalized in the terms of the decree, in matters of alimony, rights of custody, and other advantages.

The problem of not allowing a divorce where both are at fault, would never arise as a serious issue, if the courts required the parties to show an honest effort in carrying out the marital obligations. Under recrimination, if both are at fault, this is just another way of saying that the plaintiff has not made an honest effort to make his marriage succeed, and therefore cannot have a divorce even though the defendant is at fault.

Furthermore, in the supervisory field of equity, perhaps chiefly in the field of trusteeships and rcceiverships, the courts do require a showing of affirmative activity where the one appointed (trustec or receiver) is asking for court approval of his administration (sec note 12 , infra). Especially in the field of default divorce cases, this whole practice could be revitalized if the courts would require a detailed showing of affirmative effort to make the marriage succeed, much as they require a showing of affirmative effort in a trustee or receiver in the discharge of his undertakings. 
may be entirely separate from the one charged by him against the defendant. Yet if the plaintiff's offense is proved, he cannot recover against the defendant, even though the defendant is guilty as charged. ${ }^{7}$ In theory, one cancels the other as it does not elsewhere in the law.

\section{II}

\section{A SugGested Solution}

A solution for these difficulties, I think, is not some striking new approach, but merely carrying out in fact what is already implicit in every divorce petition submitted to the courts and indeed in every petition anywhere in the law. The divorce petition always states that the petitioner has been a good and loving husband (or wife) and has done all he or she could to make the marriage succeed. And generally one must come into equity with clean hands and prove not only that the defendant has done wrong, but that he, the plaintiff, has done right. The clear source of these difficulties in divorce law is that the courts do not require that these assertions of good conduct by the petitioner shall be true in fact. They are treated as mere verbiage. In a situation in which the misconduct of the defendant is usually fictional, the result is that the plaintiff may well secure the divorce although the defendant has done much more than plaintiff to live worthily in marriage and to make the marriage succeed. We have then the astounding result that the one who gets the divorce for the alleged misconduct of the defendant, has not carried out his marriage worthily and is more at fault than the defendant is.

Perhaps the analytical approach to the grounds of divorce is emphasizing the status side of marriage rather than the contract side. The particular grounds for divorce find their justification at least in part on the theory that one party has failed to carry out his particular obligations and has given specific grounds for complaint. But marriage is also a status and both parties owe a duty to strengthen and enrich this status. Looked at from this point of view, the significant issue is the contribution each makes affirmatively to the marriage partnership, rather than the particular offenses he or she may have committed. 8 Particular offenses are adapted as a rule

\footnotetext{
7 "It is well settled that a suitor for divorce cannot prevail, if open to a valid charge, by way of recrimination, of any of the causes of divorce set out in the statute. . . Recrimination as a bar to divorce is not limited to a charge of the same nature as that alleged in the libel. . . . It is sufficient if the recrimination charges any of the causes for divorce so declared in the statute. The general principle which governs in a case where one party recriminates, is that recrimination must allege a cause which the law declares sufficient for a divorce." Gardner, J., in Morrison v. Morrison, I42 Mass. 36r, 362,8 N. E. 59, 60 (1886). For the various theories urged by the courts in support of the doctrine of recrimination, see Blankenship v. Blankenship, 5 I Nev. 356, 360, 276 Pac. 9, Io (r929); Phillips v. Phillips, 48 Ohio App. 322, 324, 193 N.E. 657, 658 (1933) ("clean hands" theory); Conant v. Conant, Io Cal. $249,254,70 \mathrm{Am}$. Dec. 717 (1858) (that marriage is a contract with mutually dependent covenants and since both parties have breached the covenants the court will not aid either party); Radzinski v. Radzinski, 234 Mich. I 44, I45, 207 N. W. 82I (I926); McMillan v. McMillan, II3 Wash. 250, 25I, 193 Pac. 673 ( 1920 ) (that divorce is a remedy available only to the innocent spouse).

${ }^{8}$ If divorce were granted only on an affirmative showing of trying to make the marriage succeed, we could retain the specific grounds for divorce as a matter of allegation, and as a subsidiary ground for divorce, in the sense that the indispensable ground is that the complainant has tried to make the marriage succeed, whereas the defendant has made a less substantial effort and has committed particular offenses. This would be a very practical way to get around cruelty as a purely trivial ground for
} 
to people who live independently of each other. They should not be taken to impair indirectly the significant side of marriage-namely, the affirmative obligations of making the marriage succeed, as contrasted with the negative ones of not doing particular acts, which we all know in fact may be very trivial as interpreted by the courts and as compared with a truly affirmative attitude in honest work to make the marriage succeed. Here as everywhere we must keep our problem in sensible perspective, and not become lost in trivial artificialities. The idea of suing another on a particular ground (cruelty, desertion, etc.) is almost ridiculous. You don't have to marry in order to have legal protection against others punching your nose. Every citizen has this protection without marriage. But no one has the extraordinary privileges and opportunities of affirmative service, found in marriage, without the official sanction of the state in authorizing this extraordinary relation of marriage. ${ }^{9}$ Not only is this true from the authority of the state, but it is equally true from the express agreement of the parties. Each promises to love and to cherish the other, in sickness and in health, until death does them part. Neither promises not to punch the nose of the other nor to come home in a drunken condition.

A much closer analogy for the termination of marriage than that of particular offenses, is the well-established practice of a court of equity in terminating a partnership, or in administering an active enterprise under a receivership, or indeed, in the whole field of the law of trusts. In each of these instances we have a status to interpret and an active enterprise to administer, and in each case the court considers affirmative conduct and the honest advantages of the enterprise so far as effective work alone is concerned. Indeed, we have the general rule that partners cannot sue each other at law on partnership matters, ${ }^{10}$ with a corresponding practice that a partnership is not dissolved by a court of equity because of particular wrong acts.11 It is only dissolved upon a fair consideration of the entire enterprise and in keeping with the equitable claims of all the parties, especially in the light of how much

divorce. The plaintiff would have to make a positive showing himself, and the defendant would lose primarily because he did not correspondingly try to make the marriage succeed. These specific allegations of cruelty, which are really trivial, would then sink into their proper place as incidental illustrations of the defendant's failure to make the marriage succeed.

The test of making the marriage succeed, would automatically take care of the wcak side of recrimination in divorce law. There would always be some difference between the effort of the plaintiff and that of the defendant in making the marriage succeed. If the court thought it best to grant a divorce, it could grant it to the one who had tried hardest to make his marriage succed, and it could place the particular allegations for divorce within that pattern and subject to that primary judgment. Thus the absolute stalemate of no divorce for either under recrimination when both are at fault would not occur. The new test of making the marriage succeed would always involve some differences, and the old basis of stalemate would be gone.

${ }^{10}$ The case of Douthit v. Douthit, 133 Ind. 26,32 N. E. 715 (1892), recognizes this general rule, but with certain exceptions under particular fact situations as regards the state of the partncrship affairs.

${ }^{11}$ Cash v. Earnshaw, 66 Ill. 402 ( 1872 ); Gerard v. Goteau, 84 Ill. I2I (1876). It was held in the Cash case that it is not for every act of misconduct on the part of one partner that a court of equity, at the instance of the other partner, will dissolve a partnership and close up its affairs; that to justify such an extraordinary interposition, a strong and clear case must be made out, of positive and meditated abuse; and that for minor misconduct or grievances, involving no permanent mischief, a court of equity will ordinarily go no further than to act upon the faulty partner by way of injunction. 
honest work each has done. The same is true in judging the continuance of a receivership, and the administration of an active trust. ${ }^{12}$

\section{III}

\section{Marriage in the Cycle of the Family}

Perhaps a final consideration is this. The plain fact is that marriage not only deals with human life as other legal relationships do not, but also is a necessary part of the cycle of the family in which each of us is child and husband or wife and father or mother, all three at succeeding stages. The result is that this continuity means the continuity of life itself on this earth and the constant recurrence of new life, with each playing not one part, but all three of these very dissimilar parts, although at different times.

Without wishing to assert a fixed and literal succession in this matter, this basic cycle of life and of succeeding relationships which this life presupposes, is obvious. Any analytical construction of the law that does obvious violence to this factual structure, is headed for trouble. Of course you have to have a special method for handling marriages and particularly the dissolution of marriages. The relations themselves are truly unique. They are like nothing else in the law, and for that matter, like nothing else in this world. Put it this way; if there were no children in the world, life as we know it would cease on this planet when those now living are dead. Is there any other legal relationship that involves such truly awful consequences as this? I suggest therefore that we drop the particular grounds for divorce except as incidental guides, and that the test for any divorce shall be whether the complainant has made a substantial effort to make his marriage succeed..$^{13}$

${ }^{12} 3$ Scotr oN Trusts, $\$ 329 \mathrm{~A}$, p. 1794 : Hinds v. Hinds, I26 Me. 521 , I40 Atl. I89 (1928). It has been held that where a trust is to terminate on the divorce of the beneficiary, and she secures a divorce solely for the purpose of terminating the trust and with the intention to remarry her husband, the court will not terminate the trust. In re Vetter's Estate, $308 \mathrm{~Pa} .447,162$ Atl. 303 (1932). In Gifford v. Smiley, 27I Mass. 467, I7I N. E. 645 (I930), it was provided that the trustee should pay the income of the trust fund to certain beneficiaries, and should pay out of the trust estate $\$ 1,000$ to each beneficiary who should earn and save $\$ 1,000$. The court held that it would not order such payment to be made by the trustee to a beneficiary unless the beneficiary proved he had complied with the provisions of the trust agreement. Thus the court refused to terminate the trust by paying out the corpus until the beneficiaries had performed the affirmative acts required of them; and conversely, the trustec was not permitted to terminate the trust until the affirmative acts required of him (requiring proof of the performance of the condition by the beneficiary) had been performed.

A court which has discretionary power to appoint a receiver and confers upon him certain functions may put an end to them whenever it deems it expedient to do so, but like all other judicial action resting in sound discretion, its exercise should always be grounded on some consideration of justice or convenience. It should never be exercised capriciously or arbitrarily, but only for cause. McCullough v. Merchants Loan \& Trust Co., 29 N. J. Eq. 2I7, 218 (1878). See also Pagett v. Brooks, I40 Ala. 257, 260,37 So. 263,264 (1904).

${ }^{13}$ In considering this new technique, one thinks at once of difficult divorce or easy divorce, according perhaps to the pattern of New York as against the pattern of Nevada. Under the new plan, what would happen to this great divergence between the states, which has been a stumbling block to so many worthy efforts to improve divorce law? Perhaps some of these difficulties will be worked out in view of experience after the new plan has been used for some time. In general, however, I think the divergence between the states would continue substantially as it is now. Unless changed by statute, New York would continue to grant divorce only on a finding of adultery, but even adultery would be a subsidiary issue in securing a divorce to the main one of making the marriage succeed. The chief 
He or she owes that much not only on the basis of the promise creating the marriage but also as a public as well as a private duty in preserving the stability and the cultural values that are found in marriage and upon which all of us justly rely, whether consciously or unconsciously, in preserving our whole way of life. If the good life in marriage in terms of what people do is dropped, and the whole thing becomes a matter of trivialities, with each doing nothing affirmatively, but seeking only some triviality for destroying this good way of living itself, then in sober fact our civilization will not have the substance and strength to continue.

I would add, that the judge would probably not grant divorce except when both the plaintiff and the defendant have made some honest effort to make the marriage succeed, unless the plaintiff has made a final effort, and further pressure by the court in securing cooperation from the defendant seems futile.

Quite frankly, marriage is the most private of all relationships, but the marriage institution is not a purely private one, paradoxical as this may seem. Marriage carries with it amazing privileges. These are not given without appropriate duties also. Indeed we not only require the duties, but our way of life makes these necessary. Whatever one's view of marriage may be, surely no one is prepared to say that we could take all our present stability and source of worthy living from marriage, and leave it merely a trivial, selfish relationship, without taking from our whole way of life elements of strength that our total human capacities cannot lose and at the same time survive in our increasingly difficult and complex world.

effect of the proposal would be to reduce divorces, at least to eliminate the "frothy" ones, the ones that pretty clearly are needless and usually harmful to both parties. These divorces occur throughout most of the states, not only in the easy-divorce states of Nevada, Florida, and six or seven others. In all the other states (some 44) the new method would retain the technical grounds for divorce while emphasizing the contribution to the marriage, and putting the specific ground into a proper and subordinate place.

Perhaps there is one final question-the question of the purely individualistic theory of marriage, in which the marriage is viewed purely from the contract point of view, and it is said that husband and wife should have practically free divorce. No doubt this view is held not only by many people of limited cultural powers, but, at least privately, by some of the moral pillars of the community, who still believe in easy divoree for themselves although they would restrict it for others.

Surely the serious answer to this is that marriage is not an individual and private contract. Marriage is absolutely controlled by the state. There is no such thing as marriage without statc approval, even on a technical ground, in the common law itself. Similarly, divorce is impossible except under conditions imposed by the state, and those conditions, in keeping wth the real interests of people everywhere, are that there be reasonable stability to marriage so that, with remarkable parallelism, we may have reasonable stability in all our ways of life, for the necessary health and strength of the nation. From the point of view then of what public marriage and divorce law should be, it surely is a fair understanding, and indeed acquiesced in by people generally, that the great privileges of marriage to the individual, and the great cultural opportunities of marriage to the whole community, mean that the individual must work hard to make the marriage succeed before he is permitted any possibility of divorce, as a condition of being permitted to live in marriage in the first place. He owes this element of effort, whatever the incidental inconvenience or unhappiness may be, in order to make his contribution to the moral and cultural quality and stability of the community itself, which is so significantly affected (some would say controlled) by the moral and cultural quality of the marriage. 